\title{
'That's how you make the most out of a stay': Positionings within, and perspectives on, the truly intercultural experience during study abroad
}

\author{
Lídia Gallego-Balsà - Universitat de Lleida \\ lgallegobalsa@dal.udl.cat
}

Rebut / Received: 1-6-17

Acceptat / Accepted: 18-9-17

Resum. 'Això sí que és aprofitar una estada': Posicionaments i perspectives sobre com fer una estada a l'estranger verdaderament intercultural. Tradicionalment, una estada a l'estranger es percep com a una oportunitat de millorar el coneixement en una llengua estrangera en submergir-se en la cultura d'aquell país. Tanmateix, no tots els estudiants se submergeixen en la cultura d'acollida de la mateixa manera. Aquest estudi, dut a terme en una universitat catalana, compara el posicionament de professors de llengua i estudiants internacionals respecte a com fer que l'estada a l'estranger sigui verdaderament intercultural i la importància d'aprenendre les llengües locals. L'anàlisi ens aporta dos resultats principals. D’una banda, els professors de llengua legitimen l'experiència d'immersió total en la cultura local, ja que consideren que així s'assoleix un nivell de competència més elevat en la llengua estrangera. La seva visió, lògica des de la perspectiva de professors de llengua, contrasta amb la dels estudiants, els quals tendeixen a interactuar principalment amb altres estudiants internacionals a causa de la manca d'oportunitats que tenen d'entrar en xarxes socials locals.

Paraules clau: estudiar a l'estranger, posicionament, interculturalitat, aprenentatge d'una llengua estrangera.

Abstract. 'That's how you make the most out of a stay': Positionings within, and perspectives
on, the truly intercultural experience during study abroad. Study abroad has traditionally been
perceived as an opportunity for students to learn a foreign language by immersing themselves in
the foreign language culture. However, students do so in very different ways. This paper examines
how language instructors and international students at a university in Catalonia (Spain) project
contrasting views of the 'truly' intercultural experience abroad and the importance that each 
group ascribes to learning the local language(s), Catalan and Spanish. The analysis leads to two main findings. The language instructors legitimise the experience of full immersion in the local culture as they believe that this contributes to the achievement of high levels of competence in local language(s). Nevertheless, their position stands in marked contrast to the experience of the international students, who tend to interact primarily with other international students as a result of the lack of opportunities that the local students offer them to enter local networks.

Keywords: study abroad, stance, interculturality, foreign language learning.

\section{Introduction: Study abroad in Catalonia}

Study abroad (SA) has traditionally been conceived as an efficient context to learn a foreign language, which the L2 classroom cannot emulate in terms of the quantity and quality of the input. However, not all students immerse themselves in the foreign language culture during their SA experiences and those who do, do so in very different ways (Block, 2007/2014; Kinginger, 2013). This paper examines how language instructors and international students at a university in Catalonia (henceforth, UC) project contrasting views of the "truly" intercultural experience during SA and the importance that each group ascribes to learning the local language(s), Catalan and Spanish by means of participating in socialisation networks abroad. By focusing on the role of language learning during a SA experience in the bilingual context of Catalonia, we can see the role and value of minority languages in relation to majority languages in SA programmes and how they can represent an added value or a handicap for the students' academic development and satisfaction during their stay.

Catalan universities are located in a bilingual context where a minority language, Catalan, and a majority language, Spanish, coexist. This sociolinguistic situation can persuade as well as dissuade many international students who are in the process of selecting a university for their stay abroad. The city where the UC is located is a small city in Inland Catalonia where, according to the Catalan Institute of Statistics (Institut d'Estadística de Catalunya, 2013), almost 62\% of its inhabitants speak Catalan as their usual language of communication. The proportion of Catalan at the UC is very similar. During the academic year 2010-2011, when the data for this project were collected, the distribution of the teaching languages at the UC was the following: Catalan represented the language of instruction of around 65\% of the courses, Spanish some 30\%, and English almost 5\% (reference omitted to preserve the anonymity of the university). Most exchange international students know some Spanish on arriving in Catalonia but they often have no experience of Catalan, and, in general, they show little interest in learning it (Atkinson \& Moriarty, 2012; Gallego-Balsà, 2014). Despite the efforts that Catalan universities make to present Catalan as an added value and as part of its 
authenticity (Gallego-Balsà \& Cots, 2016), international students may see the minority language as an obstacle for their social integration and their academic success.

This paper aims at analysing the language teachers' and students' perceptions on how to make the most out of a stay abroad in the specific context of a Catalan university. It shows a clash between both perspectives. Whereas the teachers see the stay in Catalonia as an opportunity for the students to integrate in local social networks and learn the local languages, the students emphasize other aspects of their stay such as travelling, living an adventure and a feeling of disappointment towards the local community, who do not appear willing to open their circle of friends to include them.

This paper is structured into four parts. First, it presents previous research on language learning during SA focusing on individual and contextual variables that affect students' linguistic and cultural development. Second, it presents stance as the methodology employed for the analysis of the data and frames this work within the context of a wider research project. Third, it presents the analysis of the data to finally draw some conclusions.

\section{Language learning and SA}

SA constitutes a hybrid variety of second language acquisition (henceforth, SLA). Whereas SLA was traditionally considered to be achieved under two circumstances, either instructed or naturalistic (Kinginger, 2009), in a SA situation, both these forms occur. Language learners have access to instruction in class but are also exposed to real life interactions in the foreign language culture. For this reason, Kinginger (2009), drawing on Ochs (2002), argues that language learning in SA is a process of socialisation and acquisition at the same level. Language socialisation focuses on the linguistic development of language learners while they are being socialised in a new environment where they learn about the practices of the new communities and the local meaning of the same practices.

Although the language gains resulting from immersion in the foreign language culture appear to be greater than those achieved inside the classroom back home, the benefits of spending a year immersed in a foreign cultural and linguistic setting depend dramatically on individual and contextual factors. For this reason, Kinginger (2011) claims that SA should not be conceived as an elixir for learning the foreign language. If we look back at previous research, we can find that the following variables have been addressed: (1) gender (Isabelli-García, 2006); (2) the instructors' teaching style (Pellegrino-Aveni, 1998, 2005); (3) the course programme (Tarp, 2006); (4) the students' expectations, motivation and power of self-regulation (Willis Allen, 2013); (5) the languages of the learning environment or linguistic diversity (Dervin, 2013); (6) intercultural development (Jackson, 2013); and (7) social networks (Coleman, 2013) and (8) contextual factors (Pérez-Vidal, 2015). I will next review the last three as relevant to this paper. 
First, Coleman (2013) proposes a model of concentric circles to explain the dynamic socialisation networks that students establish during their stay abroad. The model aims to represent the dynamic nature of friendship rather than the level of intimacy of those friendships. In other words, it does not differentiate whether the people students meet while abroad become close friends, friends or acquaintances. However, Coleman (2013) recognises that there can be a progression in the types of friends. The model looks as in Figure 1:

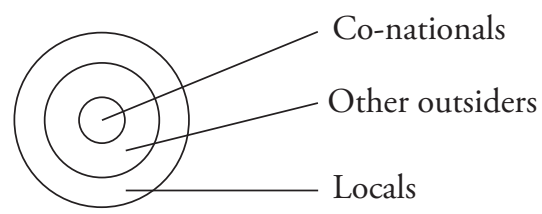

Figure i. Coleman's CONCENTRIC CIRCLE REPRESENTATION of SA SOCial NeTWorks (COleman, 2013, P. 3 I ).

This model, according to Coleman (2013), is not universal and the progression towards the local community may vary significantly depending on such individual factors as the students' motivations to meet the local community or their social skills. In the inner circle, students have fewer opportunities to practice the L2, since students' socialisation within the same national group would imply using their L1. In the outer circle, students use one or more L2s. The middle circle requires the use of a lingua franca, which tends to be English or the language of the locals.

Second, Jackson (2013) examines the intercultural development of a Hong Kong student in Canada, who assumed he had a high degree of intercultural competence prior to his stay although he had very limited previous intercultural experience. Jackson (2013) addresses the cultural clash as a factor that affects the accommodation of the student into the hosting culture, the establishment of new social networks and, therefore, the acquisition of the L2. At the beginning of his stay, the participant in this study could not recognise his incapacity to accept cultural differences, which pushed him from an international to a Chinese-only circle of friends. For instance, the participant felt uncomfortable going to the pub, a practice that put him in contact with both local and international students at the beginning. The participant went through a process of critical reflection in order to recognize cultural gaps and improve his intercultural communicative competence while abroad. Jackson concludes that this student's experience was affected by a complex intertwining of four factors: sociocultural factors (such as social networks), personality attributes (such as ethnocentrism), depth of investment in language and intercultural change, and degree of self-analysis and reflection. It would be interesting to see whether students can find alternative routes to meet international and local students when the socialization conditions are not suitable for them. 
Finally, Pérez-Vidal (2015) reports on the findings of the Study Abroad and Language Learning project, which examined the impact on advanced level university English as foreign language learners of staying in two different contexts: within (1) the ERASMUS mobility programme and (2) formal instruction. The study, which measures the learners' evolution in oral and written skills, shows that in the ERASMUS programme there are higher gains in fluency and accuracy than in formal instruction but not in phonological perception. For written skills, the study shows that most of the benefits are for the students who had been abroad. They appeared to be better in written accuracy and fluency although not in complexity. These results seem to be motivated by the communicative pressure of living abroad as it requires students to focus in the meaning of their utterances and the resolution of a task rather than in the form. The author concludes that the students who went abroad benefited the most but it was key for their success their capacity to transfer the knowledge acquired in formal instruction into the SA context and benefit from participating in meaningful interactions with speakers of the foreign language. All in all, it seems like the students' metalinguistic awareness and degree of expertise in language learning also affects their linguistic evolution abroad.

To summarise, from a holistic perspective of language learning in SA contexts, language development can be affected by the students' social skills to meet new people (whether from the local community or from the international students' community) as well as by their metalinguistic awareness and their capacity to transfer the knowledge acquired in formal instruction into the SA situation. In our specific context of research, we need to keep in mind that the students' willingness to immerse themselves in the host community intersects with the particularity of living in a bilingual context, where the minority language is the usual language for communication and the one in which the students show less competence on arrival. Therefore, international students studying in Catalonia are required to activate their social skills (making friends), their second language(s) skills and also their sociolinguistic skills (knowing the relationship between the local languages in the social context). Before we see how this intersection occurs in our context of research, the following section presents the methodology for data collection and analysis.

\section{Data and methodology}

This paper is based on the analysis of two focus group discussion sessions (FG, henceforth) organised in June 2011 within the framework of a wider ethnographic project about the internationalisation process and the language policy of a university in Catalonia (Gallego-Balsà, 2014). The participants in the first focus group session were three Catalan language teachers (Sílvia, Montse, Dolors) and one Spanish language teacher (Maria), all of them employed by the Language Service of the university, a body initially conceived to promote and protect Catalan as a language of instruction at the university, but which also takes up responsibility for the teaching of other languages. 
The participants of the second focus group session were five international students: three Chinese (Shu, Yin and Wei), one Korean (Kim) and one French (Marion), who were at the end of their stays at the UC. All the names of the participants are fictional names.

The analysis adopts a discourse analysis perspective and adopts the notion of stance (Du Bois, 2007; Jaffe, 2009) as its main analytical tool. Du Bois (2007) defines stance as "a public act by a social actor, achieved dialogically through overt communicative means (language, gesture and other symbolic forms), through which social actors simultaneously evaluate objects, position subjects (themselves and others), and align with other subjects, with respect of any salient dimension of value in the sociocultural field" (p. 169). Du Bois focuses on stance as a process and provides a strictly interactional scheme for its study, emphasizing turn-by-turn interaction.

\section{Analysis}

The analysis of the data has been divided into two parts. First, I will present the teachers' stance towards the truly intercultural experience during SA and the importance of learning the local languages. Next, the analysis will focus on the focus group discussion session with international students.

\subsection{SA as an opportunity for immersion in the local language and culture}

In the language teachers' focus-group session, the object of stance is achieved after discussing the aspects that international students value the most of the hosting city. Among these aspects, the language teachers report on the economic advantages of living in a small-size city as well as its proximity to sites of natural interest and the city of Barcelona. The discussion about the strategic geographical position of the UC develops into a discussion about whether travelling outside the host city is actually something beneficial for the students. Extract 2 shows how the teachers legitimise sporadic travelling to other cities or countries but position themselves against it when it occurs in groups made up exclusively of international students.

In extract 1, Maria reports on a conversation she had with her Czech students and explains that there is a trend among international students to visit their home university classmates in their host universities abroad (lines 1-5). This type of mobility that occurs in groups made up of co-nationals is negatively evaluated by the teachers in the following turns. The first one to position herself against it is Montse. She uses an onomatopoeic expression followed by laughter (line 6). This intervention sets the floor for Dolors to openly express her negative stance towards this trend (line 7), thereby affiliating herself with Montse, and Maria joins them categorically saying "no" (line 8) with a loud tone of voice. In the following turn, Dolors repeats 
her stance and simultaneously uses gesture to reinforce it (lines 10-11). Next, Maria adds that this type of mobility affects negatively the students' academic experience as it turns it into a sort of tourism experience (lines 12-13). She compares this way of travelling to the American soap opera The Love Boat, which explained the romantic and comic experiences of the passengers and the crew of a cruise ship.

Extract i. University turns into The Love Boat (Teachers' FG, June 20 i i)

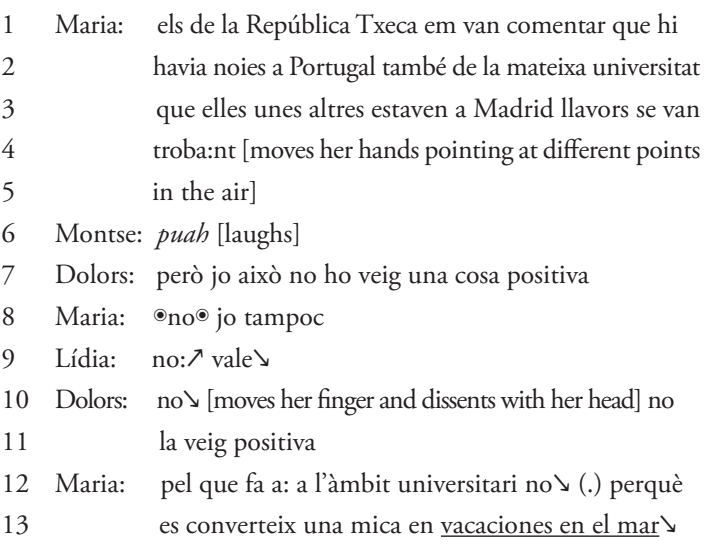

\author{
the students from Czech Republic told me that some \\ girls from the same university were studying in Portugal \\ and some other in Madrid. They meet each other

Studying abroad on The Love Boat appears as an experience during which the students set little contact with the local people. International students seem to live on the cruise ship whereas the local people do it on solid ground. In this situation, the linguistic interactions that occur among co-nationals would mainly be in the mother tongue and therefore the exposure of the students to Spanish or Catalan would be minimal. If we bear in mind Coleman's (2013) concentric circles, the students reported in extract 1 appear to willingly remain within the inner circle. The language teachers are hence, projecting an ideal of SA experience where students move, or at least try to move, towards the outer circle to reach locals with whom to practice the local languages.

This idea appears more defined in extract 2 as the teachers justify their stance. From their perspective, international students should integrate in the host place. Travelling around during the stay abroad is evaluated by Dolors and Maria as something lacking interest (lines 1-2) and illogical (lines 7-8). The stay abroad appears as an opportunity for the students to maximise their knowledge of the local context by remaining in it and putting down roots or, in other words, for immersion (line 11). From the teachers' perspective, the host context (where immersion takes place) is limited to the city or the 
region surrounding the UC. However, the students could have a wider notion of where they are doing their stay. In the case of the students referred to in extract 2, it could include all the Iberian Peninsula, as they travelled to Madrid and Portugal. This view on the side of the students could imply that from their perspective they are actually getting deep knowledge of the hosting context.

\section{Extract 2. Living the city (Teachers' FG, June 20 i i)}

1 Dolors: quin interés té $\searrow$ anar o sigui a veure

2 Maria: cap〉

3 Dolors: (...) per mi quan te'n vas a fora és per viure una

$4 \quad$ experiència $\odot^{a l}$ llo:c ${ }^{\odot}$ no vol dir que no surtis de [la

5 ciutat] però que coneguis (...) al màxim aquell lloc

6 però si si vinc aquí i mén vaig a Madrid i mén vaig a

7 Portugal ๑amb॰ els meus amics de Txèquia m: no li

$8 \quad$ veig el sentit

9 Maria: no: per res

10 Sílvia: [dissents] sí que tens raó que la idea és una mica

11

quedar-te i fer una mica d'॰arrels ${ }^{\odot}$ entre cometes

\author{
what's the point of going \\ there is no point】 \\ (...) from my perspective when you go abroad the aim is to \\ live an experience $\odot^{\circ}$ in the place $\odot$ which doesn't mean you \\ shouldn't leave [the city] but you should know that place to \\ the maximum level and if I come here and I go to Madrid \\ and I go to Portugal ๑with॰ my friends from Czech \\ Republic m: I don't see the point \\ definitely \\ [dissents] you are right the idea is \\ to stay and put down $\odot^{\text {roots }} \odot^{\text {in quotation marks }}$
}

Socialising with students with the same cultural and linguistic background in the local context is reframed by the teachers into something that affects their language development in the local languages, Spanish and Catalan. As Pérez-Vidal (2015) showed in her study, the students' willingness to engage in meaningful communication with speakers of the foreign language is key to experience linguistic gains while abroad and moving in a circle of friends made up by students from the same origin is presented by the teachers as detrimental. In extract 3, we will see how the teachers bring it to their terrain of language instructors arguing that students who immerse themselves in the host culture improve their language skills significantly more than those who do not.

In extract 3, Maria describes an alternative group of international students, a less numerous one, which, in opposition to The Love Boat students, includes students who enter local social networks (lines 1-6). The evolution of these students in Catalan and Spanish appears to be outstanding compared to those students who decide to remain within groups of co-nationals or other international students. Language learning during SA appears mostly enhanced when formal instruction (which is the teachers' job) is combined with practising outside the class (which appears as the students' duty) (lines 10-12). The SA experience that the teachers explicitly legitimise is the "language immersion" experience (line 13). 


\section{Extract 3. Full language immersion (Teachers' FG, June 20 i I)}

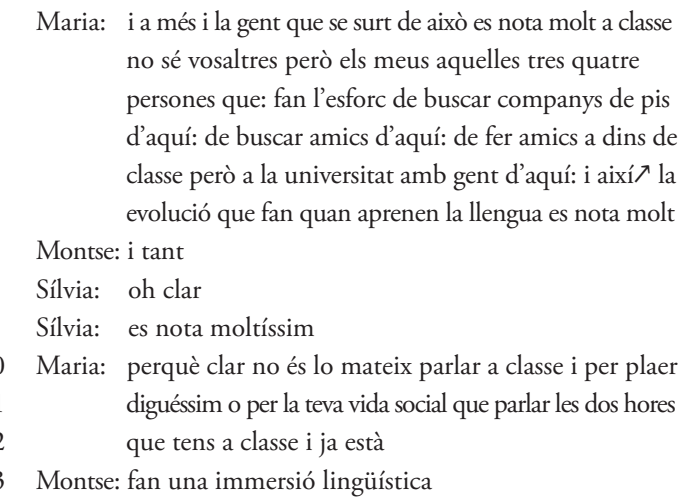

Montse: fan una immersió lingüística

\author{
and also you can see clearly in class who are those \\ students who don't do it I don't know about you but in \\ my case I can see who are those three four people who \\ make an effort to find local flatmates and local friends \\ and meet people from here at university their evolution \\ learning the language is much more evident \\ sure \\ obviously \\ it's evident \\ It is clearly not the same to speak in class and let's say \\ for pleasure or for your social life as speaking just for \\ two hours in class \\ they make a linguistic immersion
}

All in all, the language teachers seem to put the responsibility for integration on the international students. We can see that when teachers place the students as subject of their sentences: "students who don't do it" (lines 1-2, extract 3); "I go to Madrid" (line 6 , extract 2). However, they never talk about other trips that the university organises for the students (such as a trip to Barcelona during the first two weeks of their stay). In this line, the following section analyses the students' expectations and disappointments regarding their SA experience as well as their feelings of having failed in integrating themselves in the local culture.

\subsection{SA as an opportunity to expand one's knowledge of the world}

At the end of their stay, students activate two positionings in connection with the degree of integration that they have achieved during their stay. On the one hand, some international students construct a distant relationship with the local students. This appears to be due to the lack of interest that local students have in getting to know other cultures. In the following extract we can see how the home students appear as narrow-minded and unwilling to live intercultural experiences.

In extract 4, the line that keeps international and local students apart in Coleman's (2013) concentric circles is projected as impermeable. Wei states that Spanish students avoid meeting international students (lines 1-2) and that local and international students never meet (lines 4-6). Shu, Kim and Yin align with Wei in the following turns (line 7) and Shu adds that Spanish students do not feel like doing new things (lines 10-11) which, by contrast, emerges as a distinctive feature of the international students. Wei adds that among the Spanish students, Catalans are especially distant and laughs, probably as an attempt to save face in front of the interviewer, who is 
Catalan (line 13). Shu laughs as well (line 14), which helps Wei to save face. The rest, however, do not intervene.

\section{Extract 4. “Catalans are narrow-Minded” (Students' FG: June 2O i I)}

1 Wei: ellos [estudiantes españoles] no quieren juntarse con los

2 alumnos internacionales

3 Lídia: $\mathrm{mhm}$ vale

4 Wei: ellos (.) de una parte [moves his hands towards his left]

5 y nosotros de otra parte [moves his hands towards his

6 right]

7 Shu: sí:

8 Kim: [assents] sí

9 Yin: ya:

10 Shu: ellos no tienen [looks at the others] muchos ganas

Lídia: va:le

Wei: sobre todo los catalanes [laughs]

Shu: [laughs] they [Spanish students] don't want to get together with the international students

mhm right

they (.) on one side [moves his hands towards his left] and we on another side [moves his hands towards his right]

ye:s

[assents] yes

I kno:w

they don't feel [looks at the others] like doing new things

ri:ght

especially Catalan people [laughs]

[laughs]

However, a contrasting stance appears towards the way in which local Catalan students treat international students. In extract 5, we can see how Marion, a French student, positions herself against the idea that Catalan students avoid mixing up with international students.

\section{EXTRACT 5. LIVING WITH INTERNATIONAL STUDENTS VS. LIVING With LOCAL STUdents (STUdents' FG: June 2OI I)}

\footnotetext{
1 Yin: yo creo que vivir con unos ERASMUS es más

2 cómodo es verdad

3 Wei: sí entre nosotros podemos habla:r

4 Kim:

es más cómodo [assents]

Marion: yo no estoy de acuerdo[looks at Lídia] porque: vivo con catalanes y he descubrido muchas cosas que: no sé la- la cultura: lo entiendo mejor
}

I think that living with ERASMUS students is more comfortable it's true yes we can speak among us it's more comfortable [assents]

I don't agree [looks at Lídia] because

I live with Catalan people and I have discovered many things I don't know I understand the culture in a better way

First, Yin evaluates living with ERASMUS students as something more comfortable and presents it as a true fact (lines 1-2). In the following turn, Wei aligns with her and adds that it is due to the fact that it is possible to speak among the ERASMUS students. It is not clear whether the matter is that international students use Spanish as a lingua 
franca to communicate among themselves, whereas local people use Catalan, or a matter of willingness to communicate. However, Marion breaks her silence to openly disagree with the rest of the participants and construct a relationship of disaffiliation (lines 5-7). She reports living with local students and having shared knowledge with them during her stay. As a consequence, Marion considers that she understands the local culture in a better way. Marion would be a case of a student who projects a similar stance to that of the teachers, one of immersion, and who appears to be satisfied with how she lived her experience abroad. If we compare Marion to the student who appeared in Jackson's (2013) study, we can say that her immersion and her satisfaction abroad can be due to a better introduction into local social networks, a lack of ethnocentrism which enabled her to invest in language and intercultural change and the ability to reflect upon cultural difference.

The SA experience appears as an opportunity to expand one's knowledge of the world and, as we see in extract 6, the UC's location is evaluated as being too small for that purpose. Extract 6 shows how, despite having its limitations, the locality counts on what appear as two fundamental aspects of a stay abroad destination: a university and a discotheque.

\section{Extract 6. “Hay disco y hay Universidad, hay todo" (Students' FG: June 20I I )}

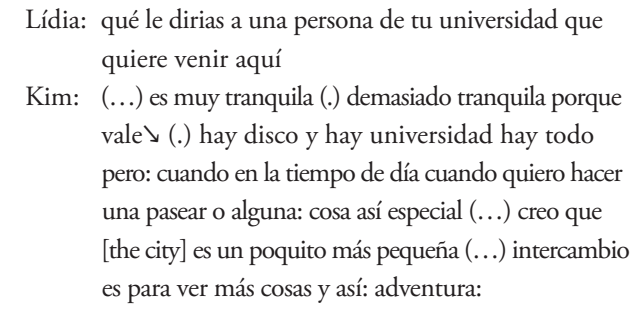

\author{
What would you say to someone from your home university \\ who wants to come here \\ (...) it is very calm (.) too quiet because \\ $\mathrm{ok} \searrow($.) there is a disco and there is a university it's everything \\ but during the day when I want to go for a walk or do \\ something special (...) I think that \\ [the city] is a bit small (...) the exchange \\ is to see more things and this way: adventure
}

The UC's location appears to lack opportunities for students to live "adventure" (line 8). It could be interpreted that, whereas the teachers see SA as an opportunity to become localised in a new culture and immersed in the local language, the students see it as an opportunity for expanding their knowledge of the world, and the way to achieve it is through adventure. When the locality does not offer enough opportunities to live adventures, the students could try to compensate it with trips to other cities.

Interestingly, the Chinese students, who evaluated the local people as narrow-minded and unwilling to participate in intercultural exchanges with the students, evaluate the city and the university as a good place for language learning (extract 7). 


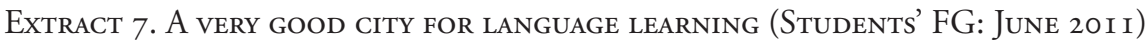

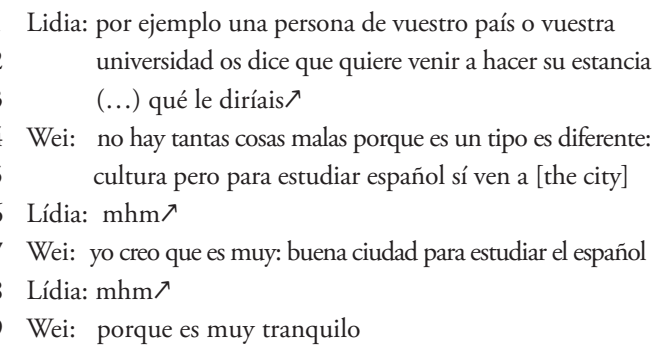

\author{
For instance if someone in your country told you \\ that they want to come to do their stay here \\ (...) what would you say $\nearrow$ \\ there aren't so many bad things because it is a different type \\ of culture but to study Spanish yes (.) come to [the city] \\ mhm $\nearrow$ \\ I think that it is a very good city to study Spanish \\ $\mathrm{mhm} \nearrow$ \\ because it is very calm
}

Lídia, the researcher, repeats the question that she posed before to Kim about what the students would say to someone who is considering the UC as a SA destination (lines 1-3). Wei replies that there are not so many bad things as it is a different kind of culture (lines 4-5). Wei seems to have interpreted that the local students' unwillingness to participate in intercultural encounters is a characteristic of the local culture and therefore, from his perspective, he is accepting cultural difference. Despite not having made local friends at the UC, Wei evaluates it as a very good place to learn Spanish (lines 5 and 7) as its city is very calm (line 9). Therefore, being in a context with very few distractions appears as a factor that helps students to focus on studying and improves their linguistic competence. The Chinese students could be pointing to a perspective on learning a foreign language as a process of intensive formal learning rather than as a process of immersion in the foreign language culture. If we bear in mind PérezVidal's (2015) study, these students seem to be doing formal instruction abroad but not transferring their knowledge acquired in formal instruction to their live abroad. It is important to bear in mind that Chinese international students at the UC participate in a special exchange programme where Spanish is formally instructed. It could be argued that the UC, through this special exchange programme and thanks to the fact that it is located in a small and calm city, has compensated the lack of opportunities for integration and immersion that Wei and the rest of Chinese students experienced during their stay, as they perceive it as a very good place to learn Spanish. Still, since the UC is located in a predomintantly Catalan-speaking area, it would have been interesting to see whether Wei, Yin and Shu would have learnt Catalan apart from Spanish if they had been able to integrate into local social networks during their stay. This is what happened with Marion, who shared a flat with Catalan home students.

\section{Conclusions}

This paper has analysed how language instructors and international students at a university in Catalonia project contrasting views of how to make the most of a stay 
abroad and the importance that each group ascribes to learning the local language(s), Catalan and Spanish by means of entering socialisation networks in the hosting context. The analysis leads to two main findings. On the one hand, the language instructors construct a stance by which they legitimise the experience of full immersion in the local culture as they believe that this approach contributes to the achievement of high levels of competence in the local language(s). In addition, they reject what we could call a more tourism-oriented approach to SA, which appears to be a more superficial experience and detrimental for the students' development of the local languages, making no reference to the responsibility of the local community to open space for the international students in their networks. Their position, logical from their perspective as language instructors, nevertheless stands in marked contrast to that of the international students. The latter (with one exception) tend to interact primarily with other international students during their stay abroad and criticise local home students for their lack of interest in participating in intercultural exchanges with them.

In Coleman's (2013) terms, the teachers position themselves against a stay abroad during which students move in the inner circle of friends or in other words, in which interactions occur among co-nationals, and construct a favourable stance towards interactions in the outer circle, i.e. between internationals and local people. The students, on their side, despite reporting to interact mainly with other international and co-national students, i.e. within Coleman's (2013) middle circle, they would ideally do it in the outer circle, thereby sharing their stance with that of the teachers.

In addition, the role of the UC in creating a course programme that ensures the Chinese students' development of Spanish is crucial to compensate their lack of integration in local social networks and satisfy their expectations on the linguistic outcomes after their year abroad. If we consider Pérez-Vidal's (2015) study on the difference between formal instruction and SA learning, we can argue that the UC has created a context of formal instruction within a SA context in which meaningful communication with speakers of the foreign language (Spanish) occurs mainly with other international students (in Coleman's 2013 middle circle). Considering that the local context is a mainly Catalan-speaking context, interactions in the outer circle, between the locals and the internationals, may involve switching from Catalan to Spanish. International students may need to assess the cost-benefit of learning the minority language (Catalan) to accommodate to the hosting culture, establish new social networks with local people and meet their expectations on intercultural change (Jackson, 2013). This was the case of Marion, the French student, who invested in reading and listening skills to gain the social benefits of having Catalan friends.

In conclusion, international students and language(s) instructors' stances towards how to make the most out of a stay abroad are not so different. They both idealise it as an experience of cultural integration and language immersion. However, their stances clash when it comes to deciding who needs to take the initiative to create intercultural encounters between the local and the international communities and practice the local 
languages. Such findings offer food for thought for university programme directors and those responsible for SA in the home institutions of students as more work appears to be necessary to reconcile the demands of the local institutions and those of international students.

\section{References}

Atkinson, D. \& Moriarty, M. (2012). “There is no excuse. Speak Catalan!" The marketing of language acquisition to mobility students. International Journal of Applied Linguistics, 22(2), 189-204. doi:10.1111/j.1473-4192.2011.00303.x

Block, D. (2007/2014). Second language identities. London: Continuum/Bloomsbury.

Coleman, J. A. (2013). Researching whole people and whole lives. In C. Kinginger (Ed.), Social and cultural aspects of language learning in study abroad (pp. 17-46). Amsterdam, Philadelphia: John Benjamins Publishing Company.

Dervin, F. (2013). Politics of identification in the use of lingua francas in student mobility to Finland and France. In C. Kinginger (Ed.), Social and cultural aspects of language learning in study abroad (pp. 101-126). Amsterdam, Philadelphia: John Benjamins Publishing.

Du Bois, J. (2007). The stance triangle. In Robert Englebretson (Ed.), Stancetaking in discourse (pp. 139-182). Amsterdam, Philadelphia: John Benjamins Publishing.

Gallego-Balsà, L. (2014). Language policy and internationalisation: The experience of international students at a Catalan university. (Unpublished Phd thesis.) Universitat de Lleida. Retrieved from handle:10803/146283/Tlgb1de2.pdf?sequence=5.

Gallego-Balsà. L., \& Cots, J. M. (2016). "Living to the rhythm of the city" Internationalisation of universities and tourism discourse in Catalonia. Language, Culture and Curriculum, 29(1), 6-21. doi:10.1080/07908318.2016.1132651

Institut d'Estadística de Catalunya (2013). Usos lingüistics. Llengua inicial, d'identificació $i$ habitual. Retrived from http://www.idescat.cat/economia/inec?tc=3\&id=da01

Isabelli-García, C. L. (2006). Study abroad social networks, motivation, and attitudes: Implications for SLA. In M. A. DuFon and E. Churchill (Eds.), Language learners in study abroad contexts (pp. 231-258). Clevedon: Multilingual Matters.

Jackson, J. (2013). The transformation of "a frog in the well": A path to a more intercultural, global mindset. In C. Kinginger (Ed.), Social and cultural aspects of language learning in study abroad (pp. 179-204). Amsterdam, Philadelphia: John Benjamins Publising.

Jaffe, A. (2009). Stance: Sociolinguistic perspectives. New York: Oxford University Press. Kinginger, C. (2009). Language learning and study abroad: A critical reading of research. New York: Palgrave Macmillan.

Kinginger, C. (2011). Enhancing language learning in study abroad. Annual Review of Applied Linguistics, 31, 58-73. doi:10.1017/S0267190511000031 
Kinginger, C. (Ed.) (2013). Social and cultural aspects of language learning in study abroad. Amsterdam, Philadelphia: John Benjamins Publishing.

Ochs, E. (2002). Becoming a speaker of culture. In C. Kramsch (Ed.) Language acquisition and language socialisation: Ecological perspectives (pp. 99-120). London, New York: Continuum.

Pellegrino Aveni, V. (1998). Student perspectives on language learning in a study abroad context. Frontiers: The interdisciplinary journal of study abroad, 4(2), 91-120. Retrieved from http://files.eric.ed.gov/fulltext/EJ608214.pdf

Pellegrino-Aveni, V. (2005). Study abroad and second language use: Constructing the self. Cambridge: Cambridge University Press.

Pérez-Vidal, C. (2015). Practice makes best: Contrasting learning contexts, comparing learner progress. International Journal of Multilingualism, 12(4), 453-470. doi:10.10 80/14790718.2015.1071019

Tarp, G. (2006). Student perspectives in short term study abroad programmes: A grounded theory study. In M. Byram and A. Feng (Eds.), Living and studying abroad (pp. 157-185). Clevedon: Multilingual Matters.

Willis Allen, H. (2013). Self-regulatory strategies of foreign language learners: From the classroom to study abroad and beyond. In C. Kinginger (Ed.), Social and cultural aspects of language learning in study abroad (pp. 47-74). New York, Philadelphia: John Benjamins Publishing.

\section{Appendix: Transcription conventions}

: long sound

$\nearrow$ rise

$\searrow$ fall

- louder

[the city] anonymised name of the city of the UC

(...) text omitted [laughs] description of communicative features which accompany language (.) pause of less than one second Underlined text: switch into Spanish Italics: onomatopoeic expression 